\title{
Interfaces
}

INTERFACES Image Texte Language

40 | 2018

Gestures and Transmission

\section{Ur-Words of the Affective Language of Gestures: The Hermeneutics of Body Movement in Aby Warburg}

Isabella Woldt

\section{(2) OpenEdition}

Journals

Electronic version

URL: http://journals.openedition.org/interfaces/605

DOI: 10.4000/interfaces.605

ISSN: 2647-6754

Publisher:

Université de Bourgogne, Université de Paris, College of the Holy Cross

\section{Printed version}

Date of publication: 21 December 2018

Number of pages: 133-157

ISSN: 1164-6225

\section{Electronic reference}

Isabella Woldt, "Ur-Words of the Affective Language of Gestures: The Hermeneutics of Body Movement in Aby Warburg", Interfaces [Online], 40 | 2018, Online since 21 December 2018, connection on 04 January 2021. URL: http://journals.openedition.org/interfaces/605 ; DOI: https://doi.org/ 10.4000/interfaces.605

\section{(c) (†)}

Les contenus de la revue Interfaces sont mis à disposition selon les termes de la Licence Creative Commons Attribution 4.0 International. 


\title{
UR-WORDS OF THE AFFECTIVE \\ LANGUAGE OF GESTURES:THE HERMENEUTICS OF BODY MOVEMENT IN ABY WARBURG
}

\author{
Isabella Woldt \\ The Warburg Institute, London
}

\begin{abstract}
The article deals with the question of the relationship between visual memory and the literary and aesthetic transfer of high-potential emotional experiences in gestures as an immanent element of cultural creativity. Against that background the article focuses on the work of the German art- and cultural historian Aby Warburg, especially his lecture and picture series entitled "Urworte leidenschaftlicher Gebärdensprache" (Ur-Words of the Affective Language of Gestures), which Warburg presented in January - February 1927 in Hamburg's Cultural Library (Kulturwissenschftliche Bibliothek). Warburg was mainly interested in the processes by which the antiquity has suirvived in visual elements. He observed that especially high-potential emotional experiences were transferred into later cultures, mainly preserved in ancient artworks, but also in literature, and the "Metamorphosis" by Ovid was one of the most important transmitters. The ancient art and literature created "ur-words", that is, original significant visual elements as gestures preserved in concepts and in cultural artefacts, which have been transferred to the later cultures and were finally one of the most important impulses for the overcoming of superstition and paganism. In the above-mentioned lecture and picture series, Warburg discusses that topic in the composition and ordering of pictures from Ovid's stories, among others "Daphne and Actaeon", "The Rape of Proserpina", "The Death of Orpheus", or "Medea killing her Children". Warburg's lecture, but especially the picture series were a methodological tool destined to present his highly complex reflections, rooted less in rhetoric than in psychology, anthropology and linguistics ca. 1900. The text is a result of a broader investigation made on the relationship between humanism and sciences, particularly psychology and anthropology in the context of Warburg's understanding of cultural and individual image memory and the role of gestures in that context.
\end{abstract}

Résumé : Cet article étudie les relations entre mémoire visuelle et le transfert dans les domaines esthétique et littéraire de gestes particulièrement chargés émotionnellement, qui informent de façon immanente la créativité des artistes. Dans ce contexte, l'article examine l'apport de l'historien de l'art et de la culture Aby Warburg, en particulier sa série de conférences illustrées intitulée "Urworte leidenschaftlicher Gebärdensprache" (les termes sources du langage affectif des gestes), qu'il prononça à Hambourg en janvier-février 1927 à la Bibliothèque culturelle (Kulturwissenschftliche Bibliothek). Warburg s'intéressait surtout à la façon dont les schémas visuels issus de l'Antiquité survivaient. Il fit observer que des expériences particulièrement chargées en émotion étaient sauvegardées dans des cultures ultérieures par le biais d'œuvres d'art et de littérature antiques et il 
étudia en particulier l'impact des Métamorphoses d'Ovide, agent de transmission de ces expériences. L'art et la littérature de l'Antiquité avaient créé des "termes sources », c'est-à-dire des éléments visuels significatifs et originaux préservés dans les œuvres, transmis à des cultures plus récentes, et qui finirent par triompher du paganisme et de la superstition. Dans la série présentée ci-dessus, Warburg explore ce sujet chez Ovide, en examinant des æeuvres illustrant "Daphné et Actéon 》, "Le viol de Proserpine 》, "La mort d'Orphée » et "Médée assassinant ses enfants ». Les conférences de Warburg et leurs illustrations lui donnèrent une méthodologie pour présenter ses réflexions complexes, fondées sur la psychologie, l'anthropologie et la linguistique des années 1900 plutôt que sur la rhétorique. La série reprend des développements antérieurs sur les rapports entre l'humanisme et les sciences, particulièrement la psychologie et l'anthropologie, telles que les comprenait Warburg, et la façon dont il les reliait à son étude des souvenirs individuels et culturels et du rôle des gestes.

Aby Warburg has played a decisive role in art history and cultural theory. His research has become a significant source and reference in the study of the origin, function and transformation of images and of the psychology of visual forms of expression. Warburg focused his academic work on the movements of the body, which he understood as the expression of the inner, highly emotional impressions of human beings. In examining these themes, Warburg mostly investigated the Renaissance as the beginning of modernity, a period that encouraged the liberation of the individual from the constraints of irrational thought. Through his work he emphasized that ultimately the highly dynamic ancient forms of bodily expression contributed to the liberation of human beings from a state of barbarism and fear into a world of rationality. Essential objects in his argumentation included the Laocoon group (Figure 1), ancient reliefs (Figure 2) and the figurative decorations on ancient vases (Figure 3). ${ }^{1}$

Warburg defined such representations of body movements as an expression of highly emotional experiences which he called "pathosformulas" (Pathosformeln) ("Dürer und die italienische Antike" 446). According to him, gestures constitute the central mode of the external manifestation of inner emotional states, whereby physical movement is part and parcel of a cognitive process involving memory in relation to linguistic concepts. Representations of movements are primary forms of the expression of intensified emotional im-pressions, called by Warburg "primordial forms" and "primordial words", or "Ur-forms" and "Ur-words" (Urworte), because they are derived from the natural forms of movements such as running, dancing or fighting. According to varying cultural conditions, "Ur-forms"

Warburg presented this crucial argumentation in his lectures (see Warburg 2012a) and in the Mnemosyne Atlas, (see for example plate 6, Der Bilderatlas MNEMOSYNE 24-25). See also his analysis of body movements on ancient vases in his essay on Dürer and Italian Antiquity ("Dürer und die italienische Antike"). Already in his dissertation Warburg analysed Sandro Botticelli's paintings The Birth of Venus (1486) and Primavera (1478) against that background (Warburg 1998c). 


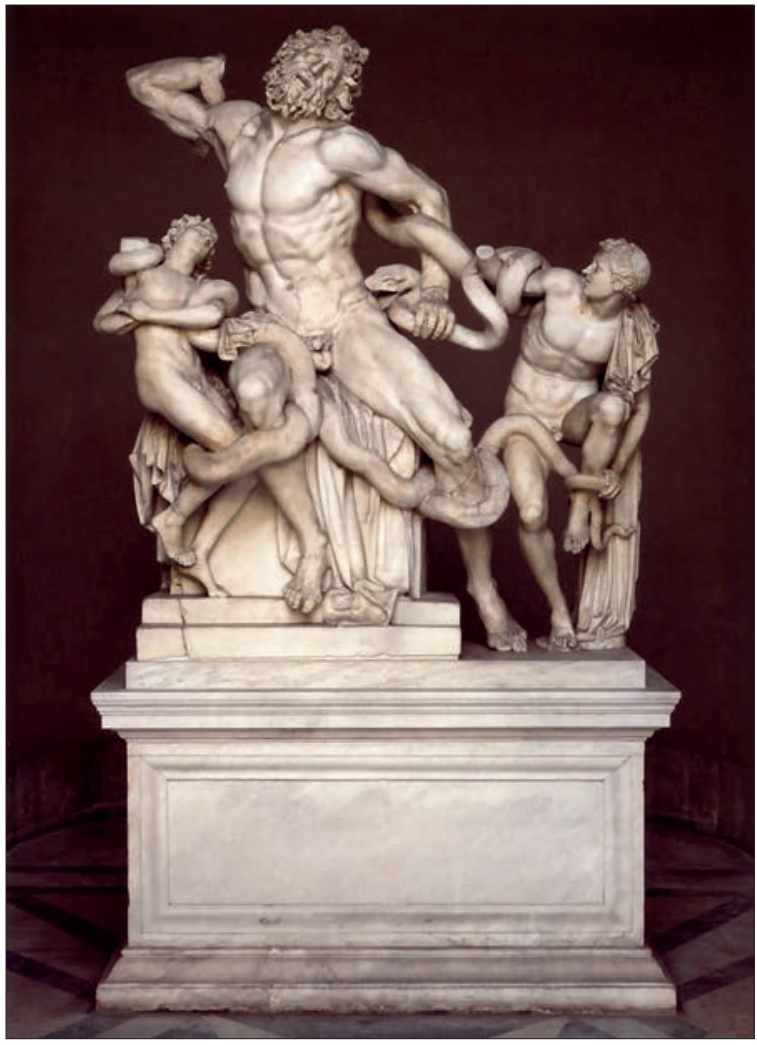

Figure 1: Athanadoros, Hagesandros, Polydoros. Laocoon and his Sons. Marble. Roman copy of a Greek original bronze statue $\left(c a .2^{\text {nd }}\right.$ century BC- $1^{\text {st }}$ century AD). Rome, Musei Vaticani, Cortile del Belvedere. Public Domain.

Figure 2: Medea's Acts in Corinth (ca. $150 \mathrm{AD})$. Marble. Roman sarcophagus. Berlin, Staatliche Museen. Antikensammlung. Public Domain.

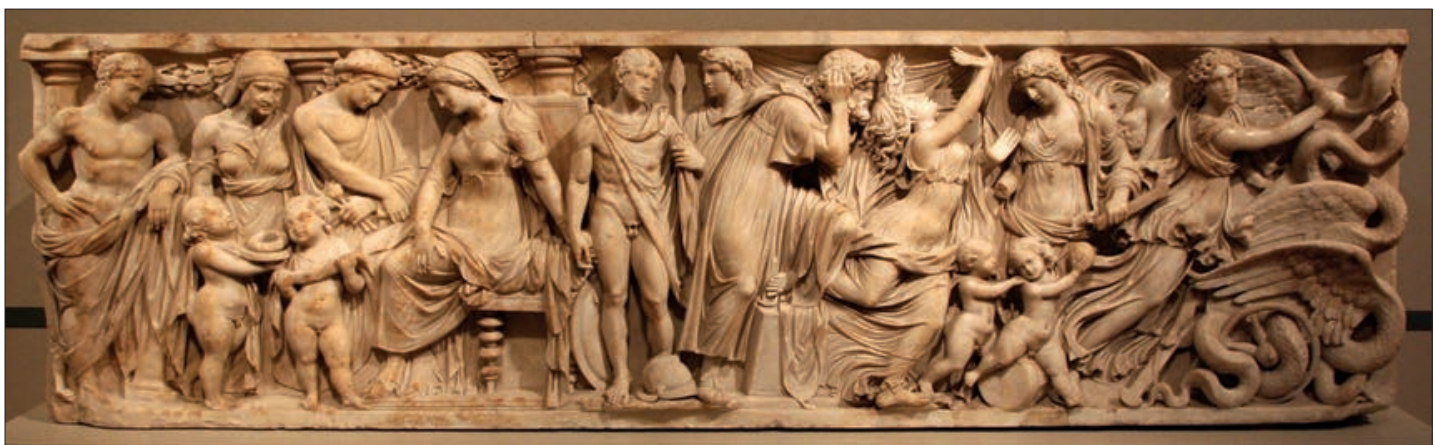




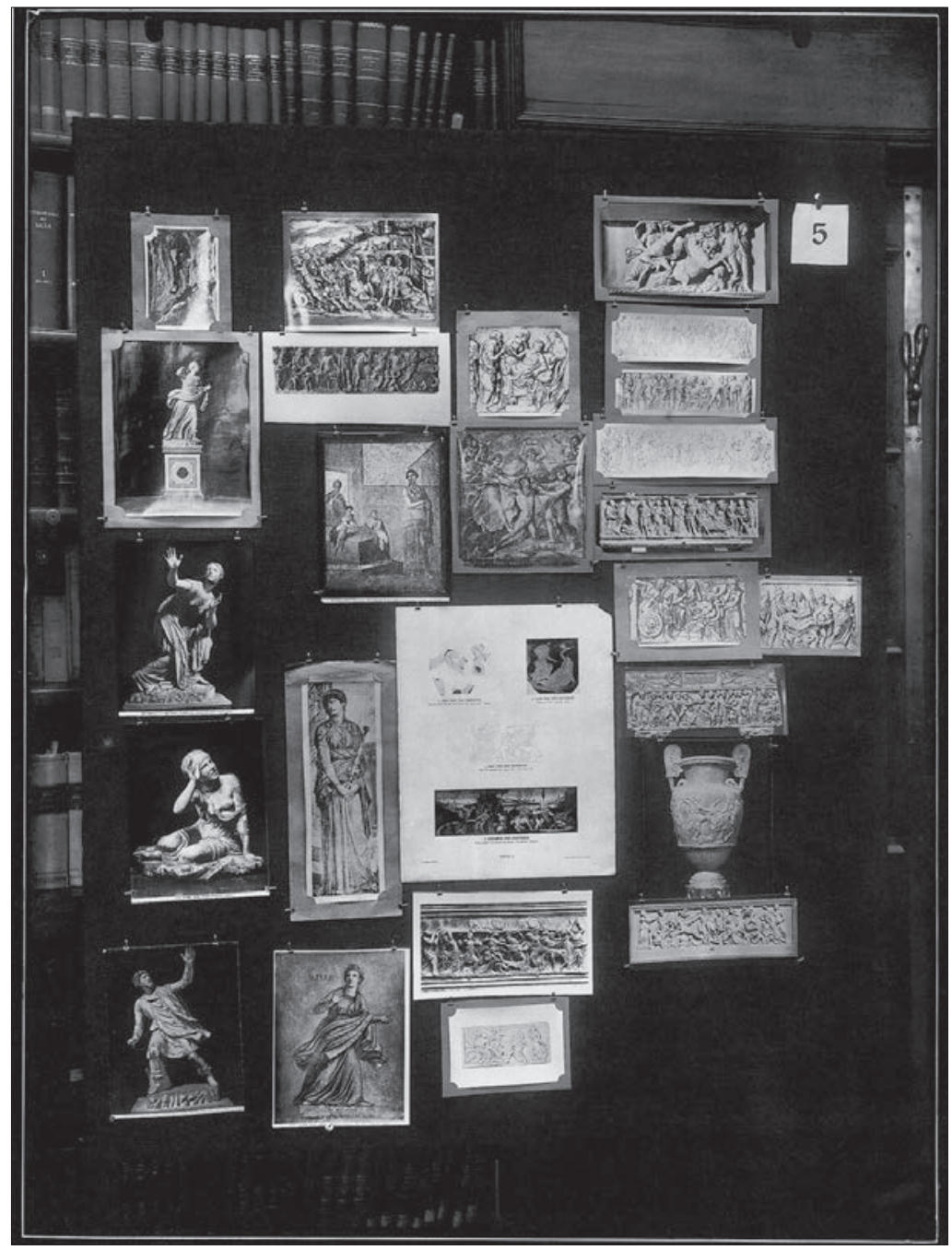

Figure 3: Aby Warburg's MNEMSOSYNE Atlas, plate 5 (1929). Aby Warburg. Der Bilderatlas MNEMOSYNE, (c) The Warburg Institute, London. 
can turn into effective symbolic pathos gestures but they are originally preserved in human memory as the equivalent concept (Begriff).

Although developed against the background of a pagan culture, as suppliers of gestural dynamism, pathosformulas played an essential role in the process of overcoming superstition itself. The medieval body, as represented on visual artefacts, appears in all its stiffness, just as, according to Warburg, the medieval world was trapped in the stiffness of the dogmatism of belief, fear and expression (mittelalterliche Ausdrucksfesseln) ("Dürer und die italienische Antike" 449). The liberation from such restrictions on the way to the Enlightenment also involved the liberation of the body via its dynamization in gestures:

The process of de-demonizing the inherited mass of impressions that encompasses the entire range of emotional gesture, from helpless melancholy to murderous cannibalism, also lends the mark of uncanny experience to the dynamics of human movement in the stages that lie in between the extremes of orgiastic seizure - states such as fighting, walking, running, dancing, grasping - which the educated individual of the Renaissance, brought up in the medieval discipline of the Church, regarded as forbidden territory, where only the godless were permitted to run riot, freely indulging their passions" (Der Bilderatlas MNEMOSYNE 3). ${ }^{2}$

For instance, Warburg refers to $15^{\text {th }}$-century Italian works of art such as Lionardo da Colle's Nozze di Pesaro (1480) (Figure 4). Although they feature the influence of more dynamic gestures borrowed from Antiquity, Da Colle's figures are nevertheless dressed in bulky costumes (called by Warburg "alla franzese") which reduce their freedom of movement and constrain their gestures (Woldt 2012a).

Warburg considered that the most dynamic expressions of gestures, as formed in Antiquity, are stored both in individual and collective memory. Moreover, he argued that according to the functioning of physiological memory, humans repeatedly visualize these expressions in this process of liberation, in the form of dynamic physical figurative gestural structures, which he called "gestural

\footnotetext{
"Der Entdemonisierungsprozeß der phobisch geprägten Eindruckserbmasse, der die ganze Skala des Ergriffenseins gebärdensprachlich umspannt, von der hilflosen Versunkenheit bis zum mörderischen Menschenfraß, verleiht der humanen Bewegungsdynamik auch in den Stadien, die zwischen den Grenzpolen des Orgiasmus liegen, dem Kämpfen, Gehen, Laufen, Tanzen, Greifen, jenen Prägrand unheimlichen Erlebens, das der in mittelalterliche[r] Kirchenzucht aufgewachsene Gebildete der Renaissance wie ein verbotenes Gebiet, wo sich nur die Gottlosen des freigelassenen Temperaments tummeln dürfen, ansah" (translated by Rampley 277).

Warburg had already discussed this in his 1905 essay "Dürer und die italienische Antike".
} 


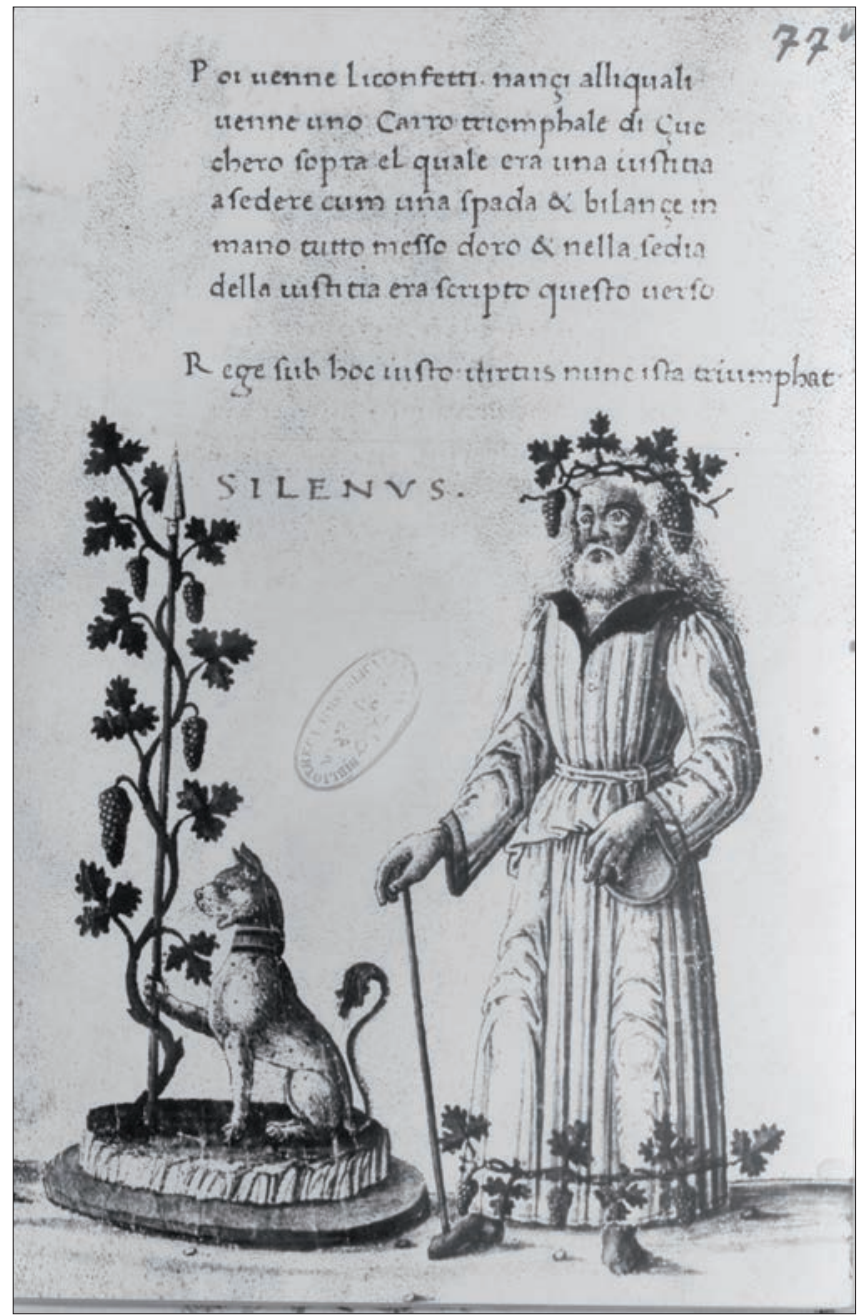

Figure 4: Lionardo Da Colle, Silen. Miniature for Nozze di Pesaro (ca. 1480). (After Nicolò d'Antonio degli Agli, Le admirande magnificentie et stupidissimi apparati delle felice nozze, celebrate da illustre signor di Pesaro, Constantino Sforza, per madonna Camille, Florence 1475). Rom. Biblioteca Vaticana, Ms. Urb. Lat. 899, fol. 77v. (C) The Warburg Institute, Photographic Collection, London. 
language" (Gebärdensprache) (Woldt 2012b). That process of expression, however, does not occur unconsciously as a symptom in the Freudian sense but manifests itself quite consciously. The artist makes a rational decision about the shape of his figures and draws from the highly dynamic ancient figurations of gestures, which, for example, persist in modern times in the form of material artefacts as expression and materialisation of a collective cultural memory, such as ancient sarcophagi or coins, statues and sculptures, as well as medals. Warburg called these structural elements "mobile image vehicles" (bewegliche Bildvehikel) because they carry the ancient concepts of body movement over time and space. ${ }^{3}$ Those elements in expressive ancient figurations are, according to Warburg, also preserved in and transmitted by ancient written forms and they remain effective in later epochs. The descriptions of gestural expressions presented in ancient literature are conceived as being strongly related to each other. ${ }^{4}$

3 Warburg used the term bewegliches Bildverhikel (mobile image vehicle) for the first time in his 1907 article on Renaissance tapestries “Arbeitende Bauern auf burgundischen Teppichen" (Warbug 1998a). At that point he introduced the term Bilderfahrzeug. The term bewegliches (mobile) sounds obsolete but it emphasized the dynamics of the discussed artefacts.

$4 \quad$ Warburg discussed that relation in his 1927 lecture on Ovid's Metamorphoses entitled "Urworte leidenschaftlicher Gebärdensprache" (Woldt 2012b). However, this must be differenciated from the linguistic processes related to the definition of Suppletivwesen presented by Hermann Osthoff (1899). That process refers to the linguistic ability to add intensifying elements into the original word in order to emphasize its meaning. Warburg compared it with the ability of artworks to intensify their expressive content by adding highly expressive dynamic gestures pre-shaped in ancient art works. See Der Bilderatlas MNEMOSYNE WARBURG: "As early as 1905 the author was helped in such efforts by Osthoff's writing on the nature of the superlative in the Indo-Germanic language: in brief he demonstrated that a change in the word root can occur in the comparison of adjectives and conjugation of verbs. Not only does the conception of the energetic identity of the intended attribute or action not suffer, even though the formal identity of the basic lexical expression has fallen away; rather, the arrival of an alien root achieves an intensification of the original meaning. A similar process can be ascertained, mutatis mutandis, in the area of the language of gesture in art when, for example, the dancing Salome from the Bible appears as a Greek maenad, or when a female servant carrying a basket of fruit in Ghirlandaio rushes by in quite conscious imitation of the Victory of a Roman triumphal arch" (translated by Rampley 278).

"Schon 1905 war dem Verfasser [...] die Schrift von Osthoff über das Suppletivwesen der Indogermanischen Sprachen zu Hilfe gekommen: er wies zusammenfassend nach, daß bei Adjektiven und Verben ein Wortstammwechsel in der Komparation oder Konjugation eintreten kann, nicht nur ohne daß die Vorstellung der energetischen Identität der gemeinten Eigenschaft oder Aktion darunter leidet, obwohl die Formale Identität des Wortgeformten Grundausdrucks wegfällt, sondern daß der Eintritt eines fremdstämmigen Ausdrucks eine Intensifikation der ursprünglichen Bedeutung bewirkt. Mutatis mutandis läßt sich ein ähnlicher Prozeß auf dem Gebiet der kunstgestaltenden Gebärdensprache feststellen, wenn etwa die tanzende Salome der Bibel wie eine griechische Mänade auftritt, oder wenn eine fruchtkorbtragende Dienerin Ghirlandajos im Stil einer ganz bewußt nachgeahmten Victorie eines römischen Triumphbogens herbeieilt" (Der Bilderatlas MNEMOSYNE 3). 
Warburg explored how a pathosformula manifests itself over time and space in persistent gestural structures, pre-shaped in ancient times. He recognized and investigated that process for the first time when analysing Albrecht Dürer's drawing The Death of Orpheus (1494) (Figure 5), in which he perceived the specific pathosformula of "fight", which is both a term and a highly expressive body movement visually manifested in the drawing (Warburg, "Dürer und die italienische Antike").

Warburg's investigation of art and culture relies on a particular interdisciplinary approach which is rooted in the context of evolutional theory and psychology. He refers in particular to Charles Darwin's theory of evolution, Theodor Piderit's theory of expression and Richard Semon's theory of the engram (Warburg, "Vom Arsenal zum Laboratorium"). The pathosformula as theoretical category derives from these considerations, and, according to Warburg, decisively regulates the function and effect of images over time and space. Therefore I will focus on the background of Warburg's hermeneutics of body movements, especially as far as the relation between word and image is concerned. First, by focusing on what Warburg generally means by pathosformula; secondly, by analyzing his investigation of the "fight" pathosformula in Dürer's Death of Orpheus in the context of his 1905 lecture on "Dürer and Italian Antiquity" ("Dürer und die italienische Antike"); finally, by showing how Warburg extended his understanding of pathosformula as a language of gestures (Gebärdensprache) in his lecture and panel exhibition "Ur-Words of the Affective Language of Gesture" (Urworte leidenschaftlicher Gebärdensprache) presented in 1927 in the reading room of his cultural library (KBW) in Hamburg. ${ }^{5}$

\section{Pathosformula}

The pathosformula is derived from concrete behavioural patterns analyzed by Charles Darwin in his biologist-evolutionary definition of human behaviour. Warburg had read Darwin's work The Expression of Emotion in Man and Animals (1872) in the early days of his research and had kept it for reference. Quite soon, however, he went beyond it. Warburg understands body movement not only, like Darwin, in a mechanistic way based on a "stimulus-reaction model", but also symbolically (see entry of May 22, 1892 in Warburg 2015). Warburg's conception relates to that of his friend, the philosopher Ernst Cassirer, who speaks in a similar context of "conscious overmoulding of motor externalizations" (bewusster Überformung motorischer Entäußerungen) (Zumbusch 182). The movements of the body, and above all basic gestures, are not merely an empty reaction to external stimuli, whereby meaning stems from an animal's biologically purposeful acts. They are rather an expression of inner affect called 


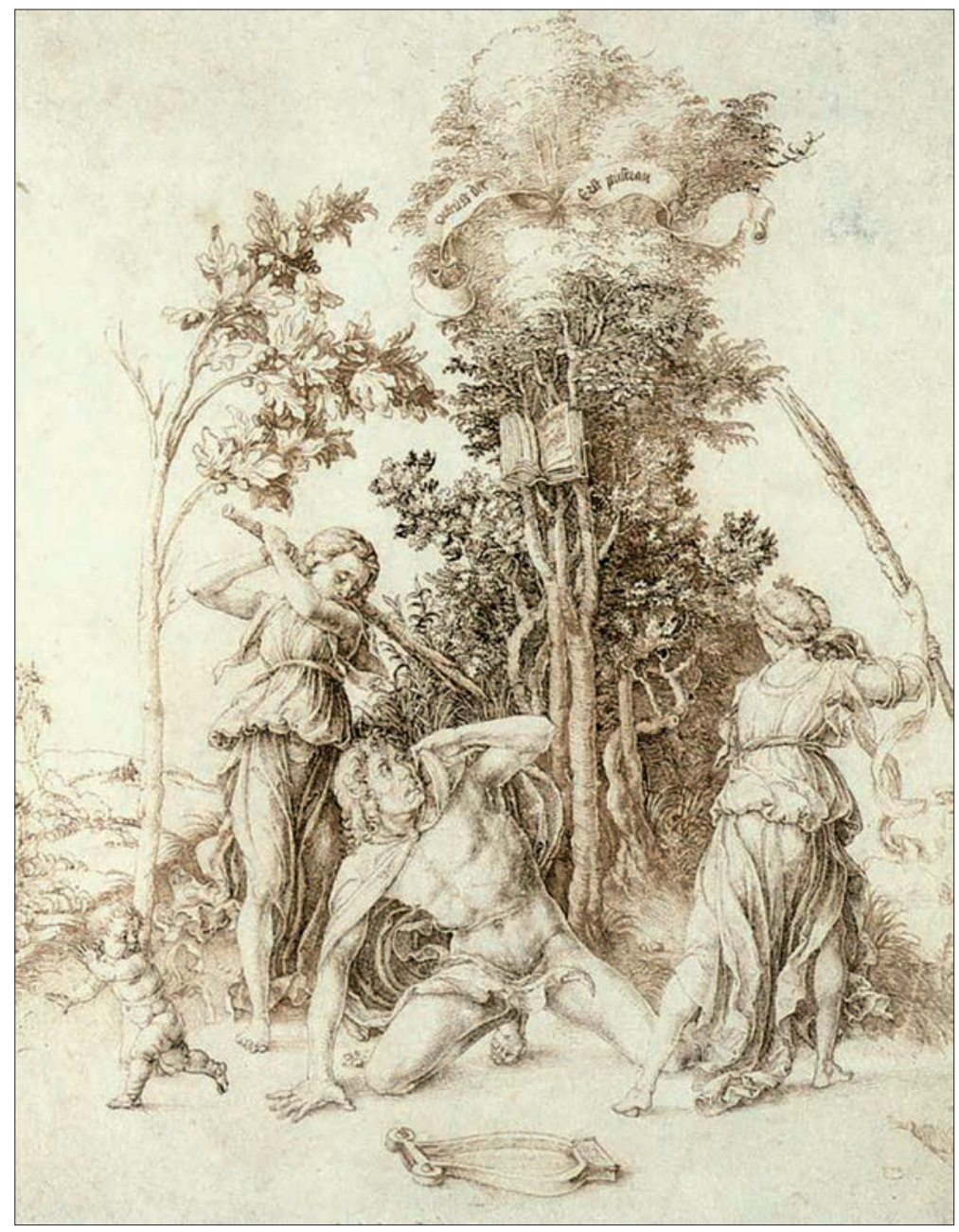

Figure 5: Albrecht Dürer, The Death of Orpheus.

Pen and ink drawing (1494). Hamburg, Hamburger Kunsthalle. Kupferstichkabinett. Public Domain. 
forth by content-driven emotions (182). Warburg also refers to the psychologist Theodor Piderit who construed the movements of facial expression "as a reflection of an inner state of the soul" in his 1867 book Mimik und Physiognomik (35, author's translation). Significantly, in a short speech delivered to the members of the board of trustees of his cultural library on December 29, 1927, Warburg described his intellectual formation thus:

To understand the human expression in the image as the pre-eminence of the practical and moving life, whether it be a religious cult or the drama of courtly festivals on the stage, was a developmental thought which I had long had, especially thanks to two books, which I read in 1888 independently in Florence, and without ever hoping that they would coincide with my art-historical experiences: Darwin's On the Expression of Mind, and Piderit's Mimik und Physiognomik. ("Vom Arsenal zum Laboratorium" 687, author's translation $)^{6}$

Investigating the afterlife of pre-shaped forms, Warburg also refers to Richard Semon's theory of the "engram". In his experiments, Semon discovered that perceived stimuli form and leave a trace in memory that is inherited, a memory track which he called "engram" (Gombrich; Semon; Woldt 2014).

Of decisive importance for that discussion of pathos and the development of the Renaissance as a phase of liberation of the individual from the constraints of dogma was the conception of "doublebodied Renaissance art", which constitutes the very centre of Warburg's work on the real beginning of the Modern Age. Warburg argued against Gotthold Ephraim Lessing's distinction of "discursive" arts, represented by literature or written words, and of "figural arts", represented by fine arts like painting or relief. This disagreement over Lessing's strict differentiation of the functions of art allowed Warburg to deal without the customary strictures with all kinds of visual elements. He also argued strongly against Hans Joachim Winckelmann's conception of a (pathetically) calm ancient art ("Vom Arsenal zum Laboratorium" 684ff). Because he considered that the Renaissance artist sought in the art of rediscovered Antiquity both pathos-laden enhanced facial expressions and classical idealizing calm, Warburg showed that Antiquity had a double-edged influence on the stylistic development of the early Renaissance - contrary to Winckelmann's primary conception of the idealizing calm of Antiquity (Warburg, "Dürer und die italienische Antike" 445).

"Den menschlichen Ausdruck im Bildwerk als Prägestück des praktischen bewegten Lebens zu begreifen - es sei nun religiöser Kult oder das Drama des höfischen Festwesen oder der Bühne - war ein Entwicklungsgedanke, auf den ich schon lange, vor allem durch zwei Bücher gekommen war, die ich in Florenz ganz unabhängig und ohne je zu hoffen, dass sie mit meinen kunstgeschichtlichen Erfahrungen zusammenfliessen würden, 1888 las: Darwins On the Expression of Mind und Piderits Mimik und Physiognomik". 


\section{Dürer's Death of Orpheus (1494)}

Warburg formulated the notion of pathosformula for the first time in his study "Dürer and Italian Antiquity" in 1905, first delivered as a lecture at the $48^{\text {th }}$ meeting of the German philologists and scholars in Hamburg. The notion relied on his interpretation of The Death of Orpheus, Dürer's 1494 drawing, now housed in the Hamburg Kunsthalle, a subject taken from Ovid's Metamorphoses (Figure 5). Through his analysis of the body rhetoric of the figures in the drawing, Warburg discovered that the composition was based on a copper engraving by an anonymous artist from Ferrara (a point I will return to below), and that the iconography of the subject had clear origins in Antiquity. Dürer's drawing shows Orpheus kneeling on the ground, trying to protect himself against the maenads pounding on him with clubs. His attribute, the lyre, is placed centrally in the foreground of the picture. While resting on the ground with his right hand, Orpheus raises his left hand to his face in an effort to protect his head from the ultimately fatal blows. This drawing exemplifies different dynamic levels: both maenads have already lifted their sticks and are about to perform their deadly attacks, one of them standing behind Orpheus and facing the viewer, the other one in front of him with her back turned to the viewer.

The dynamism of the action is emphasized quite obviously by the putto escaping on the lefthand side of the drawing, but also by the muscular tension in the bodies of all figures. The power of the action can also be seen from the aggressive posture of the maenad facing the spectator. The gestures of the raised arms as well as the billowing vestments - called "moving accessories" (bewegtes Beiwerk) - whose flowing lines flatter the body and are blown away by the wind, contribute to emphasize the energy in the bodily movement. ${ }^{7}$ The leaning tree on the left in the margin, under which Dürer locates the scene, also makes the strong winds visible.

If the observer is familiar with Ovid's myth of Orpheus, s/he recognizes in this composition the moment when the maenads have already begun to attack, as Orpheus has fallen to the ground and further actions are to be foreseen in their gestures. However, without the knowledge of the literary source of the story, the outcome of the event remains unclear. Dürer's drawing differs, for example, from the representation on an antique vase from Nola (Figure 6), which Warburg uses in his argument as a forerunner for Dürer's composition. In this picture, the maenad pierces the fallen body of Orpheus with a spear. The outcome of the event, namely the death of the god, can already be foreseen here.

Motifs such as the wind-swept hair or billowing clothes that Warburg calls bewegtes Beiwerk (moving accessory) impart dynamism to the Figure and contribute to the dynamics of the bodily pathosformula. Warburg investigated these motifs in his 1893 dissertation Sandro Botticellis Geburt der Venus und Frühling (1893) ("Sandro Botticelli"). 
As a further comparative example, Warburg also shows an outline drawing of an ancient vase from Chiusi (Figure 7).

Here, the maenads interfere with the kneeling Orpheus, whose attitude - particularly the position of leaning on the ground with his right hand, while raising his left hand to his face to protect his head from the blows - recalls both Dürer's drawing and of the Figure on the vase from Nola. The highlighted lyre, which is placed centrally in the foreground in Dürer's drawing, points to an iconographic proximity to the ancient works. However, Warburg, as already mentioned, recognized that Dürer's model was less directly related to the ancient examples than apparently to the anonymous copper engraving by an unknown Ferrarese artist (Figure 8).

Figure 8: Unknown Ferrarese artist, The Death of Orpheus (ca. 1465). Copper engraving. Hamburger Kunsthalle. Kupferstichkabinett. (C) The Warburg Institute, Photographic Collection, London.

The composition of the Italian engraving is strikingly similar: the kneeling Orpheus resting on his right hand and trying to protect his head from the attack with his left; the maenads, with similar gestures and positions, are about to beat the young god. The billowing accessory - the clothes - is shaped in the same manner. In both works the compositional arrangement of the background is pyramidal. In Dürer's drawing, the central focus is a tree in which a book and a banner are hanging, whereas an undefined monogram of the artist appears in the center of the Italian engraving. In the latter, the viewer's perspective on the scene is further enhanced by dynamic circular lines on the ground, while in Dürer's drawing the tree on the left, bent by the wind, attracts the viewer's gaze and emphasizes the dynamics of the image. This Italian engraving, which originates in ancient representations of the death of Orpheus and Pentheus, is investigated elsewhere by Warburg, as in the constellation of images in plate 5 of the Mnemosyne Atlas (Der Bilderatlas MNEMOSYNE 22-23).

The pathosformula derives from the emotional excitement expressed in the gestures of the protagonists. In Orpheus, it is derived from the moment of the fight for survival - but not in the same manner as, for example, in the highly influential Laocoon group (Figure 1). For Warburg, the Laocoon prefigures the Baroque exaggeration of the Renaissance style in the body movement, which is not present in Dürer who is looking for aesthetic and structural balance. The ancient Laocoon sculpture, discovered in 1506 (after Dürer made his drawing), marks the apex of a stylistic process which paved the way for the Baroque through Pollaiuolo's "vehement mannerism" and Mantegna's "heroic theatrical pathos" (Warburg, "Dürer und die italienische Antike" 447).

As an early example of such a gesture of self-protection, Warburg points to a representation of David holding the head of Goliath painted on a leather shield (Figure 9), which he believed to be 


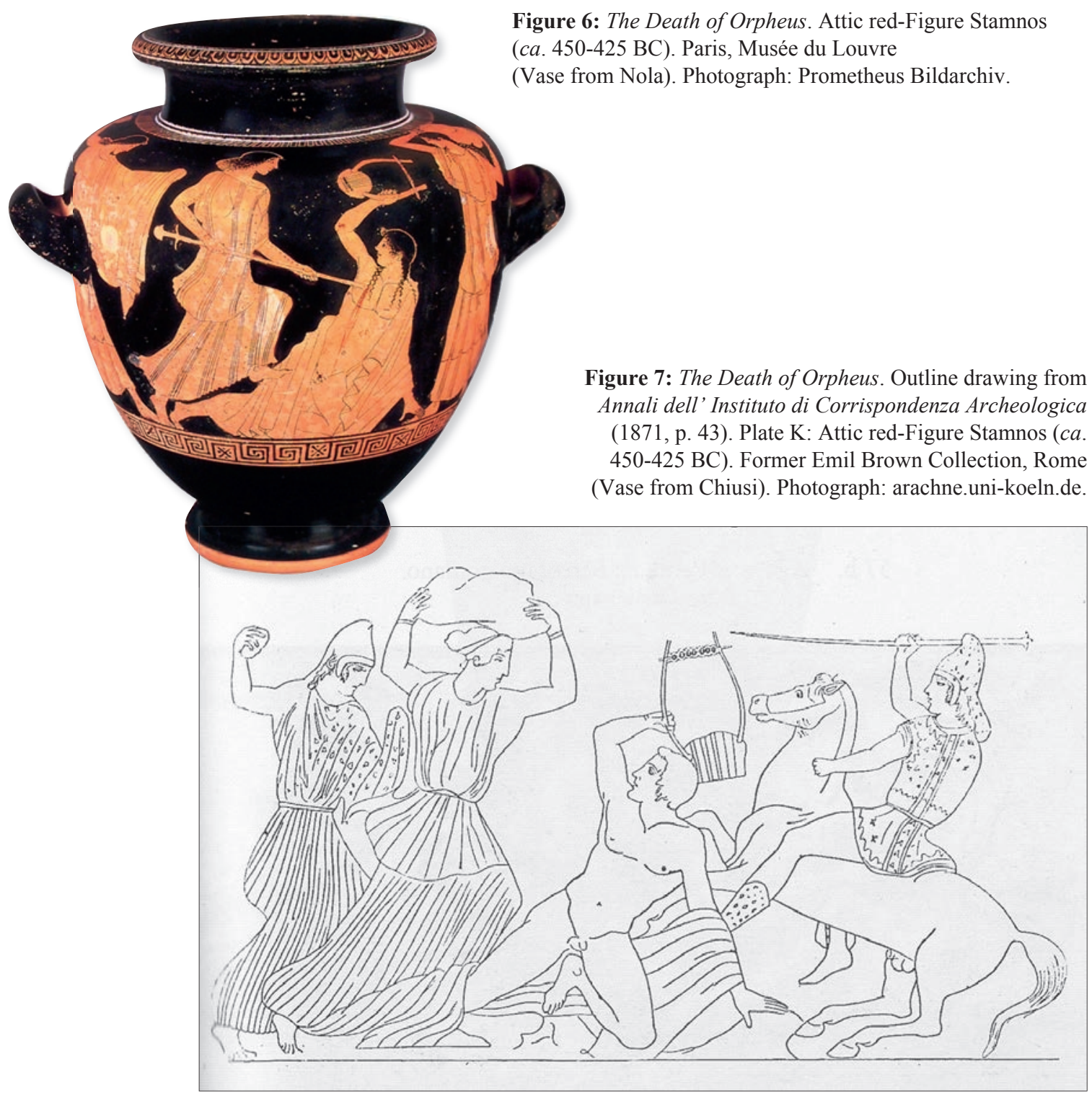


a work by Antonio Pollaiuolo. He also thought that the pathetic expansive gesture of Orpheus' left hand was inspired by the Figure of the Tutor, which is a part of the ancient Niobid group (now in the Galleria degli Uffizi in Florence) (Figure 10).

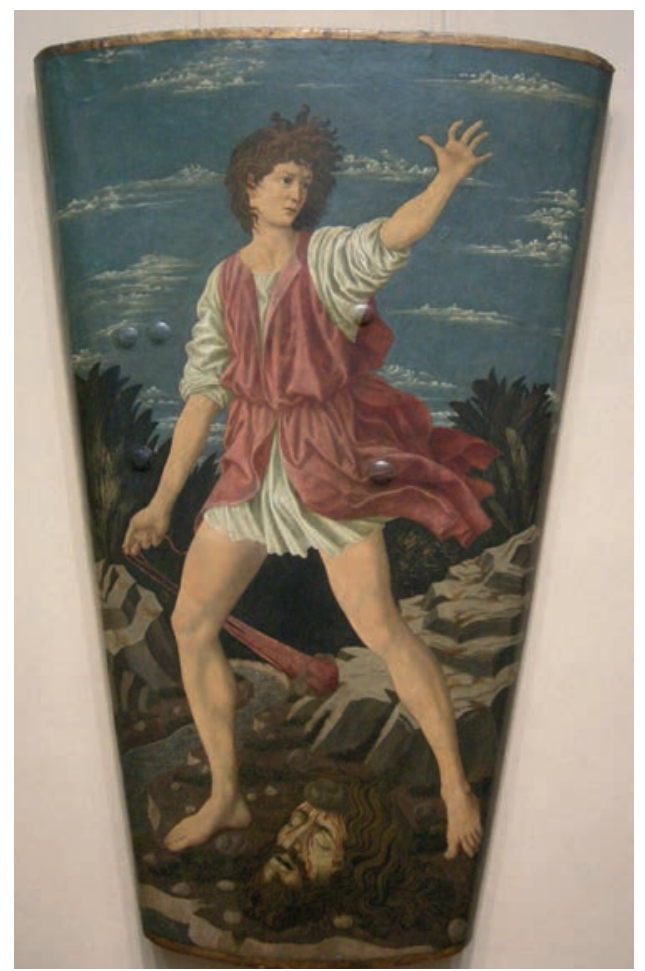

Figure 9: Del Andrea Castagno, David with the Head of Goliath (1450-1455). Tempera on leather on wood. 111.5 x $76.5 \mathrm{~cm}$. Washington D. C., National Gallery of Art. Public Domain.

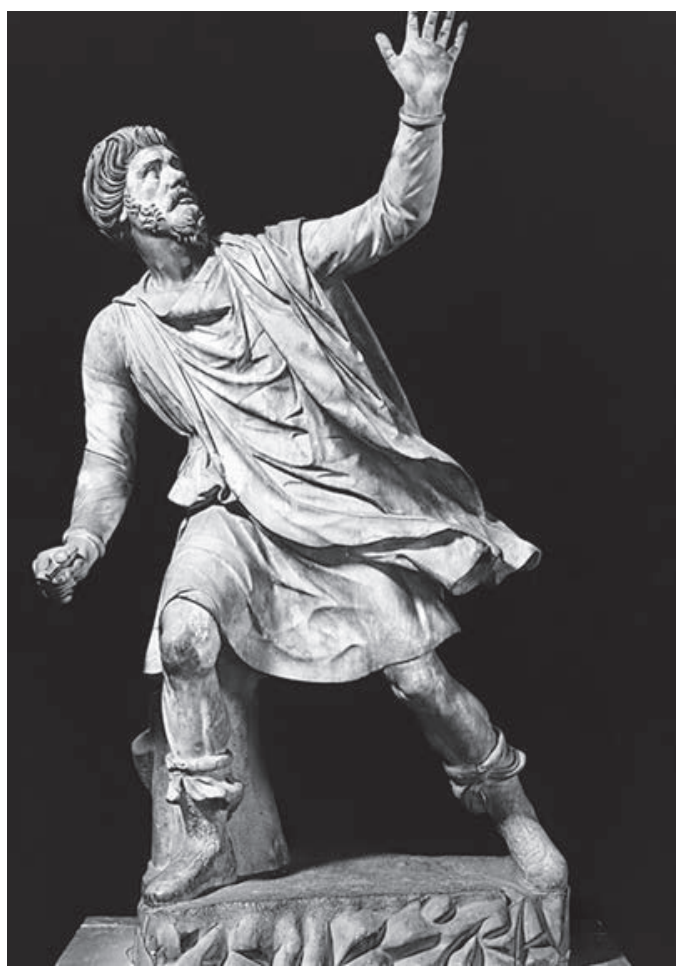

Figure 10: Tutor. Marble. Part of the Niobid group. Roman copy of a $4^{\text {th }}$-century BC Greek original. Florence, Galleria degli Uffizi. Public Domain.

Gertrud Bing, Warburg's assistant, revised the attribution of David with the Head of Goliath in the published version of the lecture, however. The work is supposed to be by Andrea del Castagno (1450-1455) and the Tutor of the Niobid group cannot have inspired Pollaiuolo because when it was 
discovered, the Figure was partly destroyed, lacking both arms ("Dürer und die italienische Antike" 625). Its ca te semble clair ?current visual presentation with both arms is a modern reconstruction. Nevertheless, Bing asserts that Castagno's expansive gesture might have been inspired by a version of Nicander of Colophon (Nikandros)'s poem "Theriaca" about venomous creatures, a $10^{\text {th }}$-century Byzantine copy of the ancient original. An illustration to verses 115-127 of "Theriaca", about the venom of snakes, contains a miniature with the depiction of the Titans fighting with reptiles (Figure 11). We recognize the Figure of a young man with the familiar gesture of fear, expressed by his uplifted hand.

Figure 11: unknown artist, Titans with Snakes. $10^{\text {th }}$-century copy of Nicander's “Theriaca”. $2^{\text {nd }}$-century $\mathrm{BC}$ parchment-miniature. Paris. Bibliothèque nationale de France. Supplément grec. 247. Public Domain.

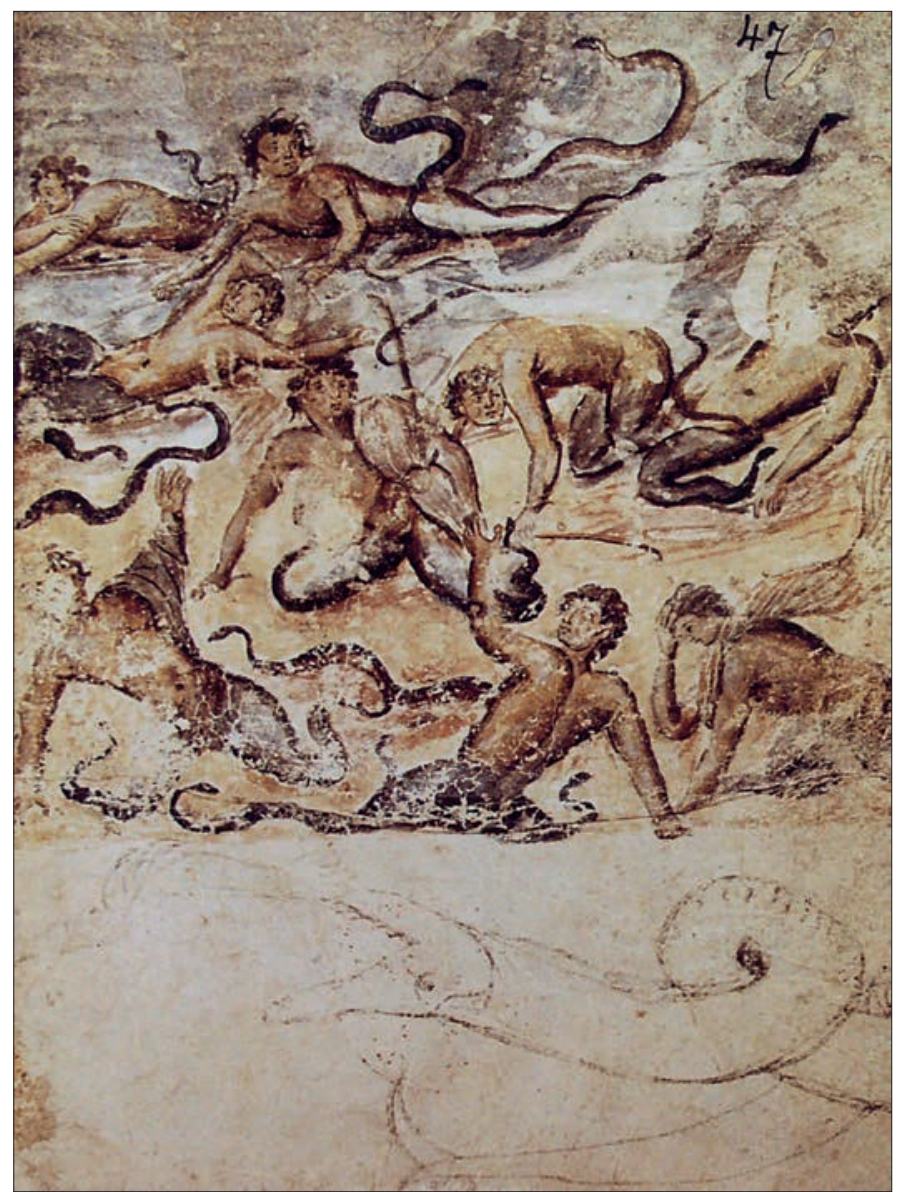


Regardless of Bing's later correction to Warburg's identification of Pollaiuolo's work, it can be generally stated that Warburg focused here on the recording of the migration of an extreme pathetic gesture language from Antiquity to the Early Italian Renaissance and on to the North in Dürer.

The "fight" pathosformula which can be identified in the iconographic examples of Dürer's Death of Orpheus and his model by the Italian Ferrarese artist, forms a figurative structure going back to ancient times. For Warburg, "fight" as a pathosformula is preserved in human memory in the form of a concept (Begriff). During the process of memorizing, the concept causes the image and the emotions to which it refers to be transferred into the cultural artefact where the formula becomes part of collective memory. More generally, the formula emerges from the constellation of the perceived and experienced emotion, the evoked movement and gesture, and their anchoring in the memory by means of concepts (Begriffe), calling forth the image, or rather a form evoked through the concept, which is then expressed in the creative process of visual expression and in its subsequent transformation.

"Fight" evokes a concept, which Warburg also calls an "Ur-Word", that is firmly anchored in the memory with a codified appearance of gestures as a determination of the scope (Umfangsbestimmung) that create the image of the concept. However, because it is constantly modified by new experiences, the structure of that image is highly transformable, even if an original trace persists as being linked to a particular emotion, reflecting thus the function of the engram, even as the Figure is combined within other constellations. In Warburg's understanding, the perception of a pathosformula as being both stable and mutable was clearly founded: its transfer to modern times occurred largely via Ovid's Metamorphoses. As we shall now see, Warburg focused on processes of mutability in his lecture and panel exhibition in 1927 called "Ur-Words of the Affective Language of Gestures" (Urworte leidenschaftlicher Gebärdensprache).

\section{“Ur-Words": Warburg's 1927 Lecture}

Against the background of the relation between image and linguistic concept, the headings under which Warburg conceived his selection of pictures for the lecture and panel exhibition entitled "Ur-Words of the Affective Language of Gestures" in 1927 concentrated on Ovidian narrative themes: "Persecution (Daphne) / Transformation (Actaeon)", "Robbery (Proserpina)", "Martyrdom (Orpheus)", "Human Sacrifice (Medea)", "Sacrificial Dance/Lament" and "Victory" characterize the Ovidian narrative. They are also to be understood as primordial words, "Ur-words" (Ur-Worte) of pathos preserved as linguistic concepts in human memory, which, if required, provide the bodily movement with a fixed structural form. 
The Death of Orpheus appears in that lecture and panel exhibition within an extended narrative context, namely in the context of "Martyrdom (Orpheus)" in panel 3 (Figure 12). The "fight" formula is exemplified by another engraving by Dürer, Effects of Jealousy, also known as Hercules Fights with Virtues against Vice (1498) (Figure 13). We recognize a familiar gesture in Virtue, who strikes with a club at the sitting figures of Vice and the Satyr. Hercules does not seem to attack the sitting group directly but to protect it by holding the club in a horizontal position. Yet Dürer obviously places Vice in the familiar defensive posture, raising her left arm to her head, in the same manner as Orpheus who protects himself in The Death of Orpheus.

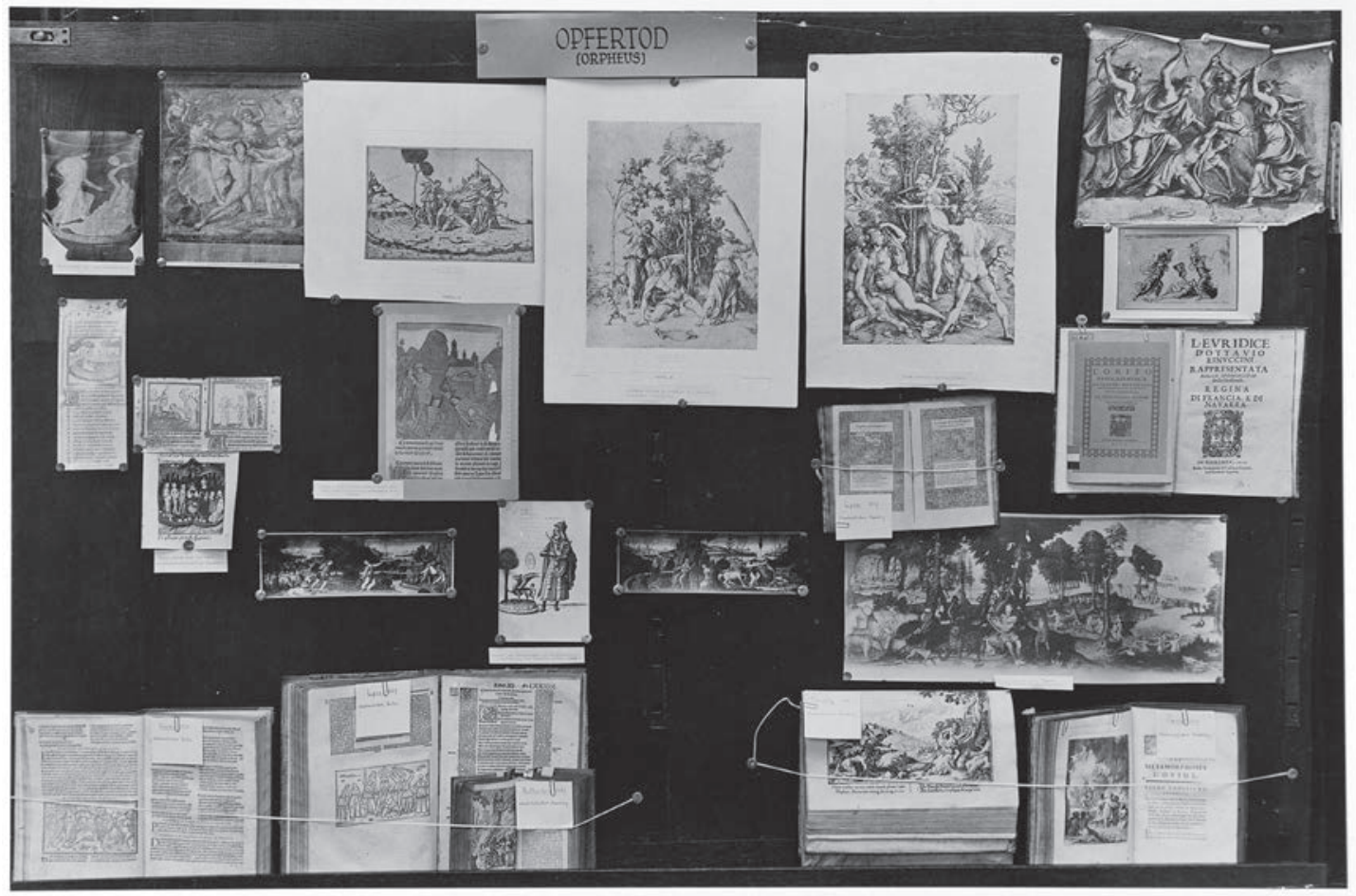

Figure 12: Aby Warburg, "Ur-words of the Affective Language of Gestures" (1927). Panel 3: Martyrdom (Orpheus). KBW, Hamburg. (C) The Warburg Institute, London. 


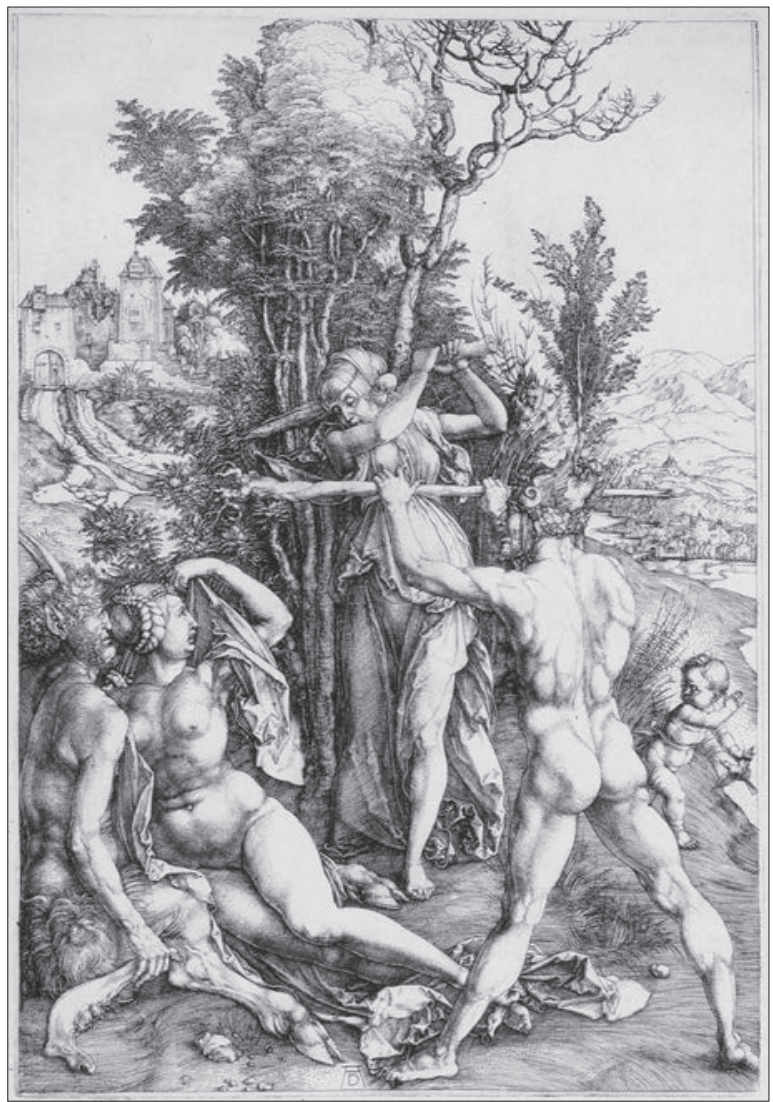

Figure 13: Albrecht Dürer, Hercules

Fights with Virtues against Vice (1498).

Copper Engraving. New York, Metropolitan

Museum of Art. Public Domain.

Ovid's Metamorphoses is an instance of one of the most important classic literary transmissions, in which descriptions have preserved the narrative of a highly emotional experience. Warburg notes:

The problem of the influence of Antiquity has, of course, led, over the years, to the investigation of the principal vehicles through which the ancient gods' world enters the European world. The main travel agency for traveling gods evidently rested for centuries in the hands of the tried-and-true enterprise: Publius Ovidius Naso and Epigones. 
[...] The mythographers' catalogue of gods becomes a treasure trove for expressive values of psychological dynamics [...]. (Warburg Institute Archive III, 97.3, fol. 1-3; author's translation) ${ }^{8}$

Knowledge of the literary sources directly evokes definite figurative constellations, especially in connection with antique visual formations:

The reawakened so-called primitive humanity manifests itself in the fact that it strives to experience the limiting values of psychic expression objectively and at the same time it wants to preserve the moderate imprinted form in precisely this intensified passion. (WIA III, 97.3, fol. 1-3, author's translation) ${ }^{9}$

In his short essay of 1898 about Botticelli, Warburg referred to the importance of Ovid's Metamorphoses for the visual art of the Early Renaissance, in order to symbolize the ideal artistic representation of life in movement. Warburg recognized that Botticelli was looking for patterns in the ancient world ("Sandro Botticelli" 65). Not unsurprisingly the first panel examined in the 1927 lecture on Ovid deals with the topic of "Transformation (Daphne) / Persecution (Actaeon)" (Figure 14), where the picture constellations were placed around Botticelli's painting Primavera (Figure 15) presented on the panel in a larger format than the other pictures.

For Warburg, Botticelli's painting became the epitome of the recollection of Antiquity and the introduction of effective movement into the painting of the early Renaissance. Warburg understood the group to the right of the composition presenting Zephyr and Flora as an erotic persecution scene, which, according to Ovid, was the story of Daphne's flight before the persecution by Apollo. Warburg also produced further interpretations of the theme of Daphne's transformation into a tree and arranged them around Botticelli's painting (Figure 16). He linked Daphne's story to the cause of her transformation by placing drawings of Apollo and the Dragon in the upper right-hand corner of the panel. He regarded the gesture of shooting a bow in Bernardo Buontalenti's drawing as an impetus for further events to support the narrative (Figure 17).

8 "Das Problem nach dem Einfluß der Antike hat im Laufe der Jahre natürlicherweise dazu geführt, die Hauptvehikel, auf denen die antike Götterwelt in die europäische einfährt, zu untersuchen. Das Hauptverkehrsbureau für reisende Götter lag Jahrhunderte lang offenbar in den Händen der bewährten Firma: Publius Ovidius Naso u[nd] Epigonen [...]. Aus dem Götterkatalog der Mythographen wird ein Schatzhaus für Ausdruckswerte seelischer Dynamik".

9 "Das wiedererwachte sogenannte primitive Menschentum äußert sich darin, daß es die Grenzwerte des psychischen Ausdrucks objektiv zu erfahren strebt und zugleich die geprägte maßvolle Form in eben dieser gesteigerten Triebhaftigkeit zu bewahren wünscht". 


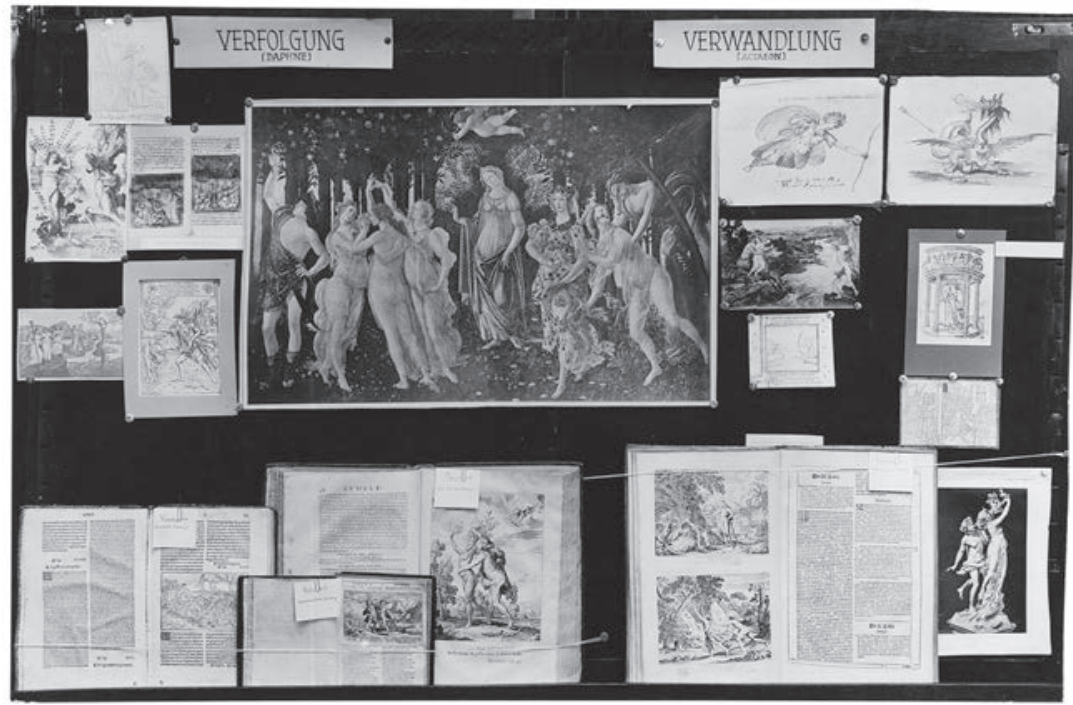

Figure 14: Aby Warburg, "Ur-words of the Affective Language of Gestures" (1927).

Panel 1: "Transformation

(Daphne)/Persecution (Actaeon)". KBW, Hamburg. (C) The Warburg Institute, London.

Figure 15: Sandro Botticelli, Primavera (ca. 1478). Oil on wood. Florence, Galleria degli Uffizi. Public Domain.

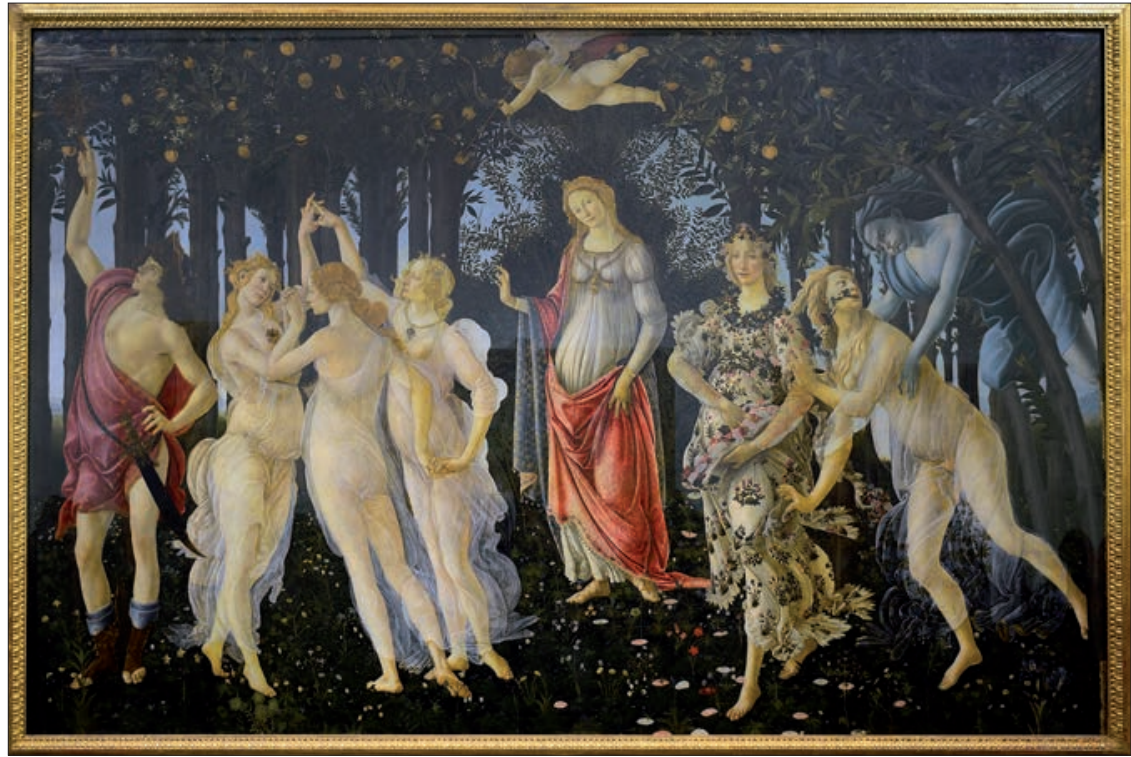




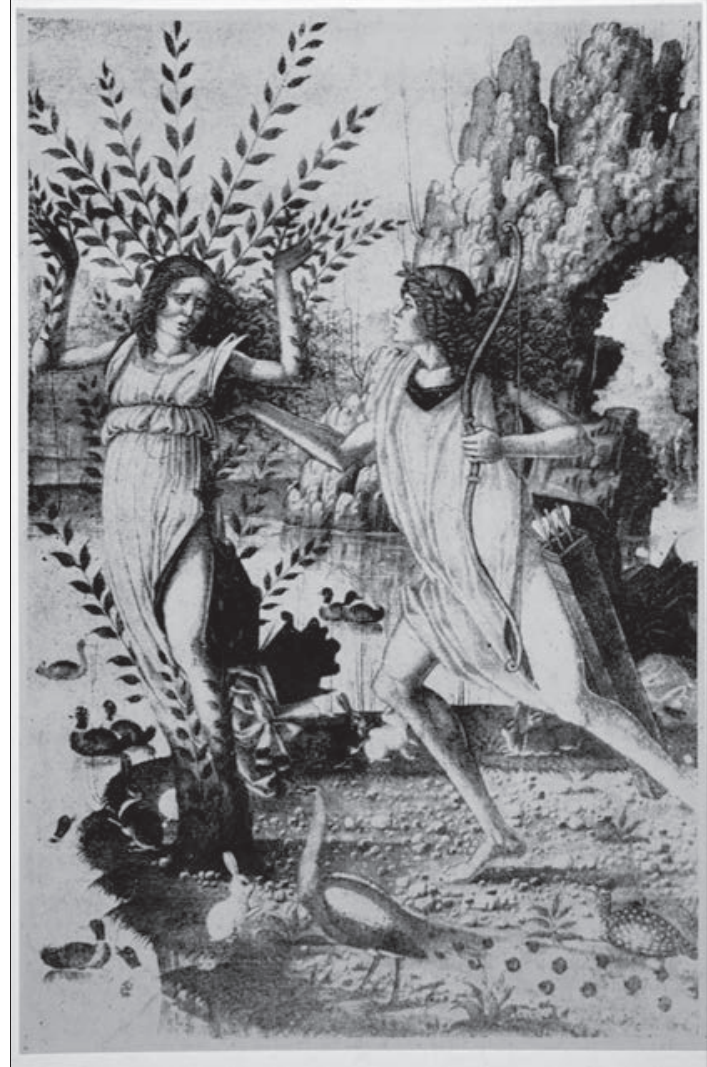

Figure 16: Giovanni Pietro Birago (attributed), Apollo and Daphne (last quarter of the $15^{\text {th }}$ century). Miniature from Daphniphilos. Wolfenbüttel, Herzog August Bibliothek. Ms. Guelf. 277.4. fol. 23r. (C) The Warburg Institute, Photographic Collection, London.

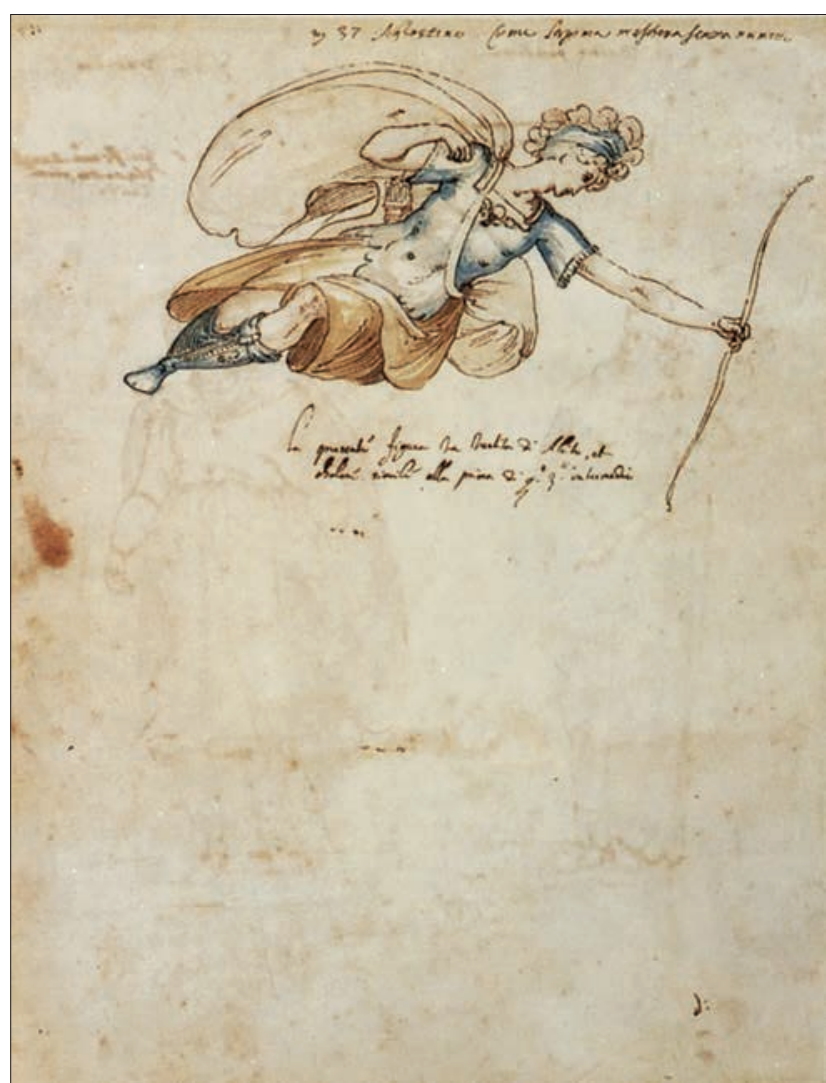

Figure 17: Bernardo Buontalenti, Flying Apollo (1589). Drawing. Illustration for the $3^{\text {rd }}$ Intermedium of La Pellegrina, on the occasion of the wedding feast of Ferdinando I de Medici and Christina of Lorraine. Florence, Biblioteca Nazionale Centrale. Palatina. C.B.3.53. Vol. 2. c. 24v. Public Domain. 
Warburg saw the link between word and image, or literature and visual representation, as strengthened by illustrated books. In the lower part of the first panel, he placed book editions of Ovid's Metamorphoses, opened on the page where the pictorial representations of Daphne's persecution and her transformation into a tree are visible. In the right-hand corner of the panel, at the end of the series of $17^{\text {th }}$-century editions, he added a photograph of Gian Lorenzo Bernini's sculpture Apollo and Daphne (Figure 18). The "figura serpentinata" - the twisted figuration of the bodies caught in an upward movement manifested in that sculpture - unites the internal and external movement of the figures. The ancient imprint of the movement ultimately leads to baroque "enhanced psychological dynamics [...] to a baroque style of sympathetic and excited pathological formulas", whose origins lie in Antiquity and are additionally promoted by the discovery of the extremely moving Figure of the Laocoon, says Warburg (Woldt 2012b 78). ${ }^{10}$

Warburg goes on to point out the parallel requirement for the pictorial expression of inner turmoil in theatrical drama, a real staging of the body movement in modern times: "Enabling the poetical-epic lyric dynamics into the real drama of the modern era" (WIA III, 97.1.1, fol. 40). ${ }^{11}$ Buontalenti's drawings of Apollo and the Dragon are sketches for a scenic representation of La Pellegrina performed on the occasion of the wedding feast of Ferdinando I de Medici and Christina of Lorraine in 1589 in Florence. The panel "Martyrdom" with the depictions of the death of Orpheus, in addition to the above-mentioned works by Dürer and the Ferrarese master, as well as their iconographic models since Antiquity, present a development in the direction of drama, which is represented in this particular case by images from the libretto of Ottavio Rinucci's Eurydice, as well as being illustrated by Monteverdi's version of the myth in his early opera L'Orpheo. In a fragment of the lecture, one can read that the ancient physical expressions of gesture in Ovid are characterized by ambivalence. According to Warburg, they embody in erotic or cultic life the passionate affection (leidenschaftliche Ergriffenheit) of Persecution, Robbery, Death and Triumph, but they "also let the sentimental-lyrical self-sense resonate, so that the pathos of the deeply tragic preface of the gestural language turns/transforms/switches into the "fairytale"" (WIA III, 97.3, fol. 1-3). ${ }^{12}$ This allows us to come back to Warburg's understanding of the Renaissance as double-bodied, characterised as it is by a highly dramatic evocative form of expression and by ideal rest, a double meaning which comes from Antiquity.

10 'Die antike Prägung führt in der barocken Skulptur zu ,gesteigerter seelischer Dynamik', sie führt, zu 'einem Barockstil mitteilsamer und erregter Pathosformeln', wie Warburg es in seinen Erläuterungen zu Ovid-Ausstellung charakterisiert hat". Author's translation here and below.

11 "Einmünden der dichterisch-epischen lyrischen Dynamik in das reale Drama der Neuzeit".

12 "die sentimental-lyrische Selbstempfindung, die die Pathetik tief tragische[n] Urwort[s] der Gebärdensprache ins 'Märchenhafte' umbiegt / transformiert/umschaltet [...], mitklingen lassen". 


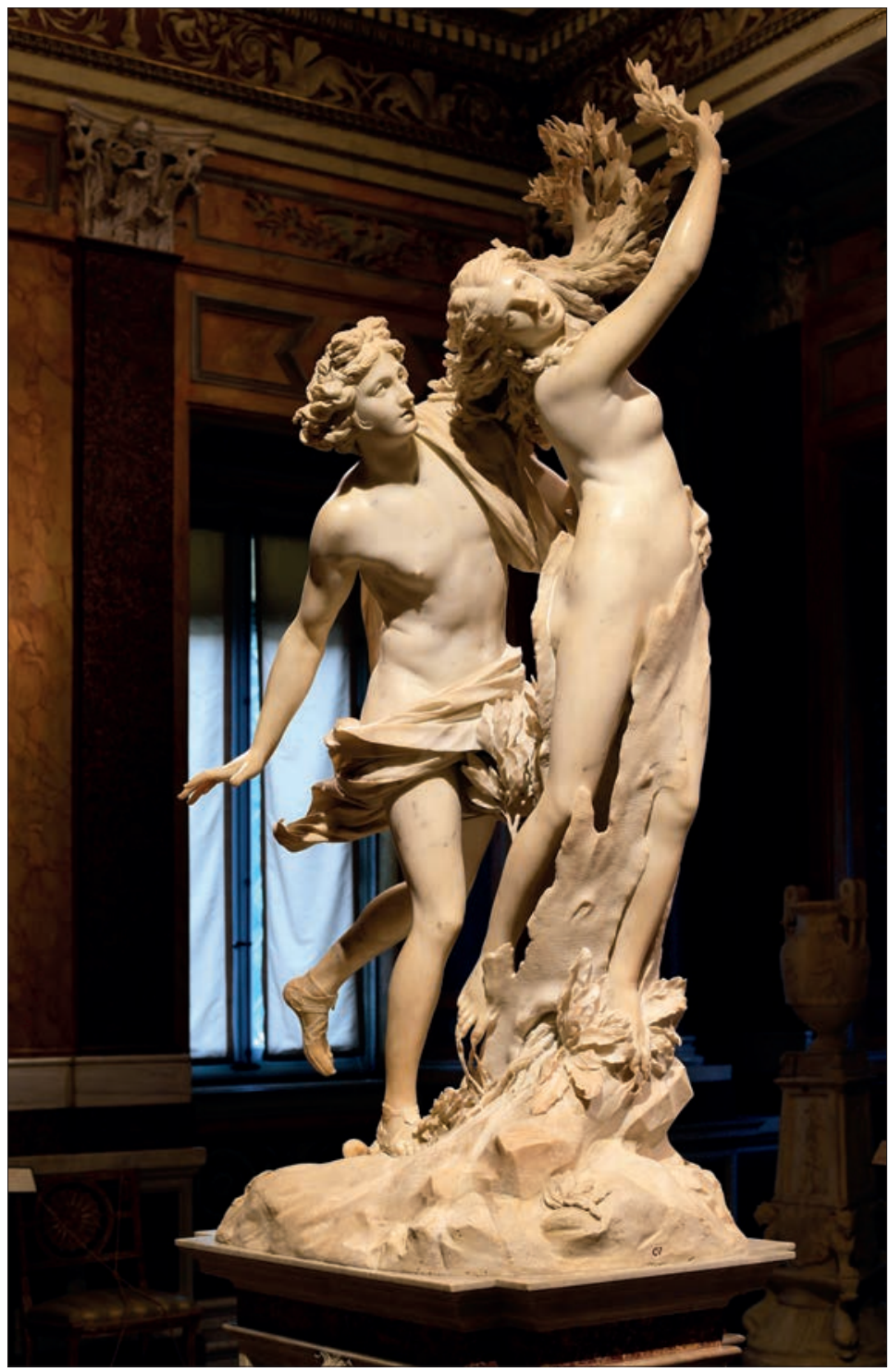

Figure 18: Gian Lorenzo Bernini, Apollo and Daphne (1622-1625). Marble. Rome, Galleria Borghese. Public Domain. 


\section{Conclusion}

Warburg's hermeneutics of body movements is anchored in the attempt to trace the process of memory in the human being, in which original emotional expressions are encoded as gestural configurations under movement-comprehending concepts that can be modified to increase drama, if necessary. The pathosformulas are anchored and fixed by those words which are conducive to motion, which is congruent with Semon's definition of the engram. According to Semon, as already mentioned, emotional impressions "coin" traces - engrams - in human memory, which can be recalled. They are still effective and capable of transformation, according to Darwin's evolutionary theory; their core, however, remains stable and can be carried on in memory, symbolically rather like the body of Daphne who turned into a tree. This is what Warburg calls "dynamoengramm", in accordance with his understanding of culture as being alive and in permanent movement (WIA III, 97.2, fol. 52-53). Daphne remains the female Nymph who, in the Ovidian narrative, can only preserve her identity through transformation.

\section{Works Cited}

DARWIN, Charles. On the Expression of Emotions in Man and Animals. London: John Murray, 1872.

GOMBRICH, Ernst. Aby Warburg. Eine intellektuelle Biographie. Frankfurt am Main: Europäische Verlagsanstalt, 1981.

LESSING, Gotthold Ephraim. Laokoon oder über die Grenzen der Mahlerey und Poesie. Berlin: Christian Friedrich Voss, 1766.

OSTHOFF, Hermann. Vom Suppletivwesen der indogermanischen Sprachen. Akademische Rede zur Feier des Geburtstagsfestes des höchstseligen Grossherzogs Karl Friedrich am 22. November 1899 bei dem Vortrag des Jahresberichts und der Verkündung der akademischen Preise gehalten. Heidelberg: Universitätsbuchdruckerei von J. Hörning, 1899.

PIDERIT, Theodor. Mimik und Physiognomik. 1867. Detmold: Meyersche Verlag, 1919.

RAMPLEY, Matthew. “Aby Warburg. The Absorption of the Expressive Values of the Past". Art in Translation 1:2 (2009): 273-283.

SEMON, Richard. Die Mneme als erhaltendes Prinzip im Wechsel des organischen Geschehens. 1904. Leipzig: Engelmann, 1908.

WARBURG, Aby. Aby Warburg. Bilderreihen und Ausstellungen. Gesammelte Schriften. Studienausgabe. Vol. II.2. Eds. Uwe Fleckner and Isabella Woldt. Berlin: Akademie Verlag, 2012a. 
-. Aby Warburg. Der Bilderatlas MNEMOSYNE. Gesammelte Schriften. Studienausgabe. Vol. II.1. Ed. Martin Warnke, with the cooperation of Claudia Brink. Berlin: Akademie Verlag, 2000.

-. Aby Warburg. Fragmente zur Ausdruckskunde. Gesammelte Schriften. Studienausgabe. Vol. IV. Eds. Ulrich Pfisterer and Hans Christian Hönes. Berlin: Akademie Verlag, 2015.

—. "Arbeitende Bauern auf burgundischen Teppichen". 1907. Aby Warburg. Die Erneuerung der heidnischen Antike. Kulturwissenschaftliche Beiträge zur Geschichte der europäischen Renaissance. Gesammelte Schriften. Studienausgabe. Vol. I.1. Eds. Horst Bredekamp and Michael Diers. Berlin: Akademie Verlag, 1998a. 221-231.

—. "Dürer und die italienische Antike". 1905. Aby Warburg. Die Erneuerung der heidnischen Antike. Kulturwissenschaftliche Beiträge zur Geschichte der europäischen Renaissance. Gesammelte Schriften. Studienausgabe. Vol. I.2. Eds. Horst Bredekamp and Michael Diers. Berlin: Akademie Verlag, 1998b. 443-449.

—. "Sandro Botticelli". 1898. Aby Warburg. Die Erneuerung der heidnischen Antike. Kulturwissenschaftliche Beiträge zur Geschichte der europäischen Renaissance. Gesammelte Schriften. Studienausgabe. Vol. I.1. Eds. Horst Bredekamp and Michael Diers. Berlin: Akademie Verlag: 1998c. 1-59. 61-68.

—. "Sandro Botticellis Geburt der Venus und Frühling”. 1893. Aby Warburg. Die Erneuerung der heidnischen Antike. Kulturwissenschaftliche Beiträge zur Geschichte der europäischen Renaissance. Gesammelte Schriften. Studienausgabe. Vol. I.1. Eds. Horst Bredekamp and Michael Diers. Berlin: Akademie Verlag: 1998d. 1-59.

—. "Vom Arsenal zum Laboratorium". Aby Warburg. Werke in einem Band. Eds. Martin Treml, Sigrid Weigel and Perdita Ladwig. Berlin: Suhrkamp, 2012b. 683-693.

Warburg Institute Archive. III. 97.3, fol. 1-3.

-. 97.1.1, fol. 40 .

-. 97.2, fol. 52-53.

WOLDT, Isabella. “Aby Warburg. Bilder aus dem Festwesen der Renaissance”. Aby Warburg. Bilderreihen und Ausstellungen. Gesammelte Schriften. Studienausgabe. Vol. II. 2. Eds. Uwe Fleckner and Isabella Woldt. Berlin: Akademie Verlag, 2012a. 275-301.

—. "Aby Warburg. Urworte leidenschaftlicher Gebärdensprache”. Aby Warburg. Bilderreihen und Ausstellungen. Gesammelte Schriften. Studienausgabe. Vol. II. 2. Eds. Uwe Fleckner and Isabella Woldt. Berlin: Akademie Verlag, 2012b. 73-97.

—. "The Operating Principle of Picture Series. Aby Warburg's Theory of the Function of Image Memory and the Renaissance Festival's Pictures". Ikon 7 (2014): 33-48.

ZUMBUSCH, Cornelia. Wissenschaft in Bildern. Symbol und dialektisches Bild in Aby Warburgs MnemosyneAtlas und Walter Benjamin Passagen-Werk. Berlin: Akademie Verlag, 2004 (Studien aus dem Warburg Haus, 8). 